FACTA UNIVERSITATIS

Series: Linguistics and Literature Vol. 16, N² 2, 2018, pp. 133-156

https://doi.org/10.22190/FULL1802133V

Original Scientific Paper

\title{
USING THINK ALOUD PROTOCOLS TO ASSESS \\ THE USE OF THE DEFINITE ARTICLE WITH SERBIAN STUDENTS OF ENGLISH
}

UDC 811.111’367.632-057.87(497.11)

\section{Marta Veličković}

University of Niš, Faculty of Philosophy, Niš, Serbia

\begin{abstract}
One of the issues which has not received enough attention in the Serbian linguistic environment is how Serbian (L1) learners of English (L2) decide which criteria are sufficient and appropriate for the use of the definite article in English. The success that linguists would have in mapping these criteria could make it possible for us to identify key problem areas in this case, and thus provide our students with appropriate and explicit input regarding how to better understand the use of the definite article. What this type of knowledge could lead to is a more specialized approach to teaching articles to non-native speakers (NNS) in the L1 Serbian/L2 English speaker community. With this aim in mind, we have carried out a pilot study which included six NNS of English, seniors at the English Department of the Faculty of Philosophy, University of Niš. Using the method of the thinkaloud protocol and a specially-designed fill-in-the-blank task, we attempted to elicit information from our respondents regarding which rules for definite article use, whether specific or non-specific, they rely on and how they account for the use of the definite article in select anaphoric definite and associative definite contexts.
\end{abstract}

Key words: Serbian (L1) learners of English (L2), the definite article, the think-aloud protocol

\section{INTRODUCTION}

Mastering the articles of the English language is a challenging task, as indicated by various authors working with English language learners of various L1 backgrounds (cf. White 2010; Verspoor 2008 (submitted); Mayo and Hawkins 2009; Lee 2013; Ionin et al., 2004; Trenkić, 2002, 2004, 2007; Master, 1990, 2003, inter alia). Articles may be among the most frequently used words in the English language (Master, 1990), but there are still unanswered

Submitted May 18, 2018, accepted for publication September 16, 2018

Corresponding author: Marta Veličković

University of Niš Faculty of Philosophy, English Department

E-mail : marta.velickovic@filozofski.edu.rs 
questions regarding how English language learners make the choice of which articles to use in spoken or written communication.

One of the issues which has not received enough attention in the Serbian linguistic environment is how Serbian (L1) learners of English (L2) decide which criteria are sufficient and appropriate for the use of the definite article in English. The challenges which Serbian (L1) learners of English (L2) face are the result of several factors, some of which are applicable for all English language learners, irrespective of their mother tongue:

- a lack of one-form to one-meaning correspondence, since (in)definite articles can be used to convey existential presuppositions, establish referential relations, can be used attributively, or as indicators of countability and number;

- the fact that the definiteness status of nominals is not marked with overt grammatical markers but is inferred by the English language learners based on textual, contextual, and pragmatic cues (Lee, 2013);

- the existing issues with most course books used in the teaching process are that they provide insufficient explanations and that they require English language learners to memorize the rules of definite article use (White 2010, Verspoor submitted).

Others are specific only to the Serbian language and L1 Serbian learners of English (L2):

- that Serbian does not have a system of articles;

- that Serbian codes specificity, while English codes definiteness (Trenkić 2002, 2004, 2007 2009);

- that in Serbian there is a variety of grammatical structures used to convey specificity (certain adjectives, the numeral jedan, demonstratives such as taj and indefinite pronouns such as neki, etc.).

Trenkić (2004: 1406) provided a distinction between specificity and definiteness which pertains directly to Serbian:

"The crucial difference that separates definite from specific, as we understand it, is to whom something is identifiable: to both the speaker and the hearer (definite), or just the speaker (specific)." (original emphasis)

Working within a broader scope but along a similar vein, Radden and Dirven (2007) pointed out the difference between specific and definite reference by indicating that the speaker uses specific reference to signal to the hearer, that he, but not the hearer, has a particular referent in mind, instructing the hearer to construct a mental space for the referent in question.

"While indefinite reference was shown to be exclusive, definite reference is inclusive: a definite referent includes all the elements which form its set, i.e. it does not exclude any of them. [...] In order to refer to all elements that are included in a set, the set has to be mentally shared by speaker and hearer. There are different ways of making a set accessible to both speaker and hearer, and hence making the referent definite. The referent may be found in the present speech situation, it may be evoked in the current discourse, or it may be part of the social and cultural world shared by speaker and hearer. Accordingly, we have three subtypes of definite reference, which will be discussed in the following sections: (i) deictic reference, (ii) discourse reference and (iii) unique reference." (Trenkić 2004: 96-97).

Although a layman might say that proper knowledge of definite article use is not obligatory for communication to take place, at the tertiary level of education, it is the goal of any student majoring in the English language to achieve native-like proficiency. The correct use of the definite article is based on our justifiable conclusions as to what a 
cooperative native speaker of the English language would use in a certain context, and what a cooperative addressee might understand (Matthews et al., 2006). This type of proficiency is reflected in proper (in)definite article use, even though there is some indication that this may impose cognitive processing constraints inherent in spontaneous L2 production on the L2 learner. Lee (2013) agrees with Master (1990) and Trenkić (2008) that the use of the indefinite article requires a speaker to take into consideration more than just the criterion of definiteness, but to also consider countability, for example, which imposes a cognitive load on the L2 speaker and leads to lower accuracy rates for indefinite article use in English. Thus, in order to help English language learners avoid any frequently made mistakes, which manifest themselves in the form of incorrect article use/overgeneralization, or article omission altogether (Butler 2002; Jarvis and Pavlenko 2008; Hawkins 1978; Mayo and Hawkins 2009; White 2010), it is necessary to try and get a glimpse into the possible reasoning behind their choice of definite article use.

We designed a small-scale study as an attempt to elicit from Serbian (L1) learners of English (L2) the necessary information regarding why they think the definite article was (not) required in certain contexts.

In this paper we will attempt to answer the following research questions:

1. Which are the more frequently used reasons that account for the use of the definite article in English as provided by advanced Serbian (L1) learners of English (L2), specific or non-specific?

2. Is higher accuracy expected in associate definite contexts or anaphoric definite contexts, as proposed by Lee (2013)?

3. Are the explanations behind definite article use obtained in this study more or less unified? That is, is there any consistency in definite article use?

\section{THEORETICAL BACKGROUND: THE STANDARD RULES BEHIND DEFINITE ARTICLE USE AND THEIR POTENTIAL DRAWBACKS}

Current analyses of definite article use are based on the premise that articles should be studied by the linguistic sub-fields of either morphology or syntax, with a slight shift towards the cognitive framework as of late. While acknowledging their usefulness and current prevalence as the dominant explanatory frameworks for definite article use, these strictly 'grammatical' analyses of the definite article have some limitations, starting from the fact that, within this existing framework, the rules which govern the use of this article are meant to be learned by heart, to the fact that they focus solely on the grammatical and disregard the semantic component which might be found in article use (cf. White 2010; Verspoor submitted). Furthermore, not all of the uses of the definite article which can be encountered in everyday language, be it spoken or written, can be accounted for by these fixed set of rules for article use taught in most EFL/ESL classrooms. This was indicated as far back as 1949, when Otto Jespersen first made this claim in his book A Modern English Grammar, and still enjoys the support of authors to this today, including Epstein $(1999,2001)$ or Veličković (2017). ${ }^{1}$ Furthermore, there is also the prevalent problem that

\footnotetext{
${ }^{1}$ In the same vein, in 1999, Lyons indicated that several components of definiteness are needed to fully account for the scope of definite article use: identifiability and familiarity on the one hand, and uniqueness and inclusiveness on the other. Furthermore, in order to account for definite article use with uncountable and countable plural nouns, as the existing framework was mostly aimed at explaining definite article use with
} 
several rules for article use could be applied to the same context, i.e. could be used to explain the use of the definite article in a single example. It was as recently as 2002 that Huddleston and Pullum reiterated in their Cambridge Grammar of the English Language that we often have to rely on more than one criterion in order to justify the use of the definite article. ${ }^{2}$ The examples they used to illustrate this problem are the following ones (Huddleston and Pullum 2002: 368):

a) The father of one of my students rang me up last night.

In this example, the student is not actually known, s/he is unfamiliar, has not been 'identified', nor is the 'identification' of this particular referent necessary in order for referential relations to be established. As soon as the NP 'a student' was used, it was easy to establish a link between the intended referent and his parent, based on their 'association', to use the widely accepted term. We could, at the same time, claim that the father in question is identifiable because we each have one father, an explanation based on the precondition of uniqueness of the second referent in question, for the use of the definite article.

b) The first person to run the mile in under four minutes was Roger Bannister.

In this case we have both pre- and post-modification to help us identify the referent in question, which represents one possible account for the use of the definite article. At the same time, such a detailed description also meets the requirements for uniqueness, as there can be only one referent which satisfies this particular description.

Furthermore, to many English language learners, it is still unclear why it is sometimes appropriate, and at other times inappropriate, to use the definite article with various types of nouns: countable singular, countable plural, uncountable, or even abstract. Lyons (1999: 261, original emphasis), for example, lists the following examples, which illustrate situations in which the conditions for the use of the definite article have been satisfied, and yet the noun phrases are accompanied by the indefinite article or some other marker of indefiniteness:

Pass me a bucket please. (definiteness determined based on the immediate context)

Have you heard the news? A cabinet minister has just resigned; I didn't catch which one. (definiteness determined based on the wider context)

[At a wedding] Have you seen any bridesmaids? (definiteness determined based on the general situation)

Fred picked up a book, and tore out some pages. (definiteness determined based on associative anaphoric use)

It becomes clear that any typology of definite article use cannot be either exhaustive or fully 'accurate' under any given circumstances. The consequence is that it is difficult for English language learners to grasp (definite) article use if they rely solely on the rules they encounter in their course books, which in turn makes the article system of the English language a fertile ground for further study.

Since an exhaustive overview of all the ways definite article use is accounted for in the various course books used at the tertiary level of education at Serbian universities lies outside the scope of this paper, we will provide a cursory account of the most frequent

countable singular nouns, Hawkins $(1978,1991)$ in turn introduced maximality or totality into the mix. With a variety of criteria to choose from, these classifications indicate that an inclusive approach, which is currently missing, is necessary to fully account for the use of the definite article in naturally occurring language.

${ }^{2}$ Depending on the context, there may be more than one grammatically accurate choice of determiner for a given pre-nominal position, with the possibility that the choice can sometimes even be made between two articles. 
rules, ones that English language learners are most often exposed to at the English Department, Faculty of Philosophy, University of Nis. ${ }^{3}$ These rules provided a baseline of possible responses which could be expected from our respondents. Some of the most frequently used course books that English language students use during the course of their studies include A Practical English Grammar (4 ${ }^{\text {th }}$ edition, Thompson and Martinet 1986/2004), which is used mostly by beginners, and Advanced Language Practice (Vince 2003), which is used at more advanced levels. Both of these volumes offer explanations/rules based on what will be referred to as the standard or 'traditional' approach to the explanation of the use of the definite article, which is based on familiarity, identifiability, uniqueness and maximality/totality.

A Practical English Grammar contains a special section devoted to article use (1986/2004: 19-22), where the provided rules for definite article use are mostly based on uniqueness and identifiability. The instructions included therein inform English language learners to use the definite article: 1) when an object or group of objects is considered unique e.g. the earth, the sea, the sky, the equator, the stars; 2) when a noun is mentioned for the second time e.g. His car struck a tree; you can still see the mark on the tree; 3 ) when a noun is modified by a phrase or a clause e.g. the girl in blue, the man with the banner, the boy that I met, the place where I met him; 4) when a noun can represent only one thing as a result of locality e.g. Ann is in the garden (the garden of this house), Please pass the wine (the wine on the table), Similarly, the postman (the one who comes to us), the car (our car), the newspaper (the one we read); 5) with ordinal numbers and superlatives e.g. the first (week), the best day; 6) when the noun has a generic meaning e.g. The whale is in danger of becoming extinct; 7) when the followed by an adjective represents a class of people e.g. the old; 8) when the is used before certain proper names of seas, rivers, groups of islands, chains of mountains, plural names of countries e.g. the Atlantic, the Thames, the Azores, the Alps, the United States of America; and 9) with certain proper names, as in the Smiths = Mr and Mrs Smith (and children) and We have two Mr Smiths. Which do you want? I want the Mr Smith who signed this letter.

The Advanced Language Practice book also has a section devoted to the definite article (2003: 104-105), where it is clearly stated that the basic use of the definite article is with a referent that is "assumed known", and one which has already been mentioned in a particular context, which is otherwise known as referent identifiability through prior mention. The rules for definite article use outlined in this book include: 1) use in a generic sense, e.g. The tiger is threatened with extinction; 2) use with unique objects e.g. the moon, the sun; 3) use in cases when there is post-modification in the noun phrase e.g. She became the President of the United States in 1998; 4) use with musical instruments e.g. Jane plays the flute; 5) use in order to achieve emphasis e.g. This hotel is the place to stay; 6) use with geographical locations and place names e.g. the Thames; 7) use with superlatives e.g. This is the most expensive hotel in town; and 8) use for previous mention e.g. The Smiths had a son and daughter. The son was in the Army and the daughter was training to be a doctor.

In addition, two theoretical works in particular stand out in terms of their relevance to the topic at hand, and were used to design the fill-in-the-blank task used in this study. They also make up the core of the 'traditional' approach to understanding the use of the definite article in English. One is John Lyon's (1999) classification of the obligatory contexts for the use of the definite article, which include: familiarity based on situational

\footnotetext{
${ }^{3}$ For a similar account, but for a different group of English language learners, see White (2010).
} 
uses of the definite article, familiarity through general knowledge, familiarity based on the anaphoric use of the definite article, familiarity based on the associative use of the definite article, familiarity through preceding and succeeding information, and familiarity based on anticipatory anaphoric use of the definite article.

The second is Huddleston and Pullum's (2002) classification of the same contexts: identifiability through the sensory features of the situation, identifiability through the non-linguistic knowledge shared by the speaker and hearer, identifiability by virtue of prior mention, identifiability through association, identifiability through association with the object-referent, identifiability based on the modifier which enables the referent to be identified and based on the relative clause which enables the referent to be identified, and finally identifiability from the predication property.

\section{THE METHOD}

Considering the fact that English language learners' implicit knowledge does not always provide us with a sufficient data set since "the evidence stemming from learners' language production is incomplete" (Bowles 2010: 1), many processes in language learning are not directly observable from what a learner says in the target language (Corder 1975) and "it is often difficult to determine the reasoning behind language learners' target language use" (Bowles 2010: 8). Thus, a sample of the English language learner's explicit knowledge was called for. This refers in particular to the underlying decision-making process which governs language production. Therefore, I used a think-aloud protocol as the data elicitation method, along with a fill-in-the-blank-task designed especially for this purpose, during a set of interviews I carried out.

\subsection{The sample of participants}

The respondents were six students of the English Department, Faculty of Philosophy, University of Niš. They had been studying academic English at the tertiary level for what was almost a full four-year period. Seeing how the respondents were in their final year of study at the time when the interviews were conducted, they had been able to benefit from all the instruction and exposure to language which university courses have to offer, and thus represented proficient English language learners. However, although they were all the same age, and all shared the same native tongue (Serbian), not all of the respondents possessed the same level of explicit knowledge, as exemplified in their responses to the questions provided, nor was their language production in general identical during their final year of study. Participation in the interviews was voluntary, which may account for the limited number of respondents.

\subsection{The measuring instrument}

\subsubsection{Think-aloud protocols: a brief overview}

The think-aloud protocol, a verbal account of L2 use, was described as a data elicitation method by Ericsson and Simon (1993), Butler (2002), Gass and Mackey (2007), Bowles (2010), and Lee (2013), etc. These protocols offer a glimpse into the decision-making process of language learners, however quick and however scant, so that "both concurrent and 
retrospective verbal reports are now generally recognized as major sources of data on subjects' cognitive processes in specific tasks" (Ericsson and Simon 1993: xi).

Think-aloud protocols have been in use since the early $20^{\text {th }}$ century, mostly in nonsecond language acquisition (non-SLA) fields, primarily psychology, dating as far back as the 1930s, with increased popularity during the 1950s, when participants in various experiments were asked to verbalize their thoughts. Their use spans both L1 research: reading and writing assessment and evaluation, and language testing, and L2 research: reading, writing, translation, interlanguage pragmatics, L2 attention and awareness studies, conversational interaction research, implicit and explicit L2 knowledge (cf. Bowles 2008).

Researchers in the field of SLA resort to think-aloud protocols in order to gain more information on learners' cognitive processes, thought processes and strategies as they interact with a specific L2. In SLA research, verbal reports can offer invaluable insight into the language learning process and access to L2 knowledge (Bowles 2008: 361; 366). So far, they have been used in picture drawing and spot-the-difference tasks in oral interaction research, role-play and discourse completion tasks in interlanguage pragmatics, and task-essential problem-solving tasks targeting morphological and syntactic L2 structures (Bowles, 2008).

Previous research based on think-aloud protocols has included beginner and adult speakers alike, usually with provisions made to consider any potential reactivity (cf. Bowles and Leow 2005). Butler (2002) interviewed Japanese learners of English once the participants had completed a fill-in-the-blank task in order to glean the reasoning behind their article choices. This allowed the author to form some kind of understanding of the metalinguistic hypotheses regarding the use of English articles. Leow and Morgan-Short (2004) discussed the possible operationalization and measurement of attention (and awareness), and in this process made use of think-aloud protocols to gather concurrent or on-line data regarding learner's cognitive processes activated during the completion of tasks involving L2 data. Wigglesworth (2005) used think-aloud protocols to investigate whether learners consciously focus on specific aspects of language and the degree to which they notice particular features. She researched L2 learning processes, especially focusing on consciousness in language learning, and concluded that learners actively need to notice the gaps in their knowledge, and to notice the significance of what they have perceived. Think-alouds in these situations allow us to collect introspective data which could help identify what students do (not) notice. The conclusion which Lee (2013) reached after using think-alouds is that

"ELLs may gradually acquire the manner in which nominal entities are constructed with regard to countability and definiteness and that learners are able to incrementally understand how the use of articles is conditioned by semantic, pragmatic, and contextual features." (Lee, 2013: iii)

\subsubsection{The fill-in-the-blank task}

The verbal reports analyzed in this small-scale study were motivated by the use of a fillin-the-blanks task. The aforementioned rules for the use of the definite article were illustrated by means of sample sentences in the task. We primarily relied on the rules/contexts classified and systematized by Lyons (1999) and Huddleston and Pullum (2002). Due to the overlap between them, seven rules/contexts for the obligatory use of the definite article finally emerged. The end result was a 31-item fill-in-the-blanks exercise 
which the respondents were meant to complete using a grammatical word they deemed appropriate. 4

Approximately one-third of the items included in the fill-in-the-blanks exercise (10 of the 31 ) required the use of either the indefinite or zero article. They were included to ensure that the respondents would give each item its due consideration, without blindly opting for the definite article, thinking that they had solved task at hand without much effort. The remaining 21 example sentences were illustrations of the seven basic rules for the use of the definite article. When possible, the sentences included in the fill-in-theblanks exercise were selected from among the examples provided by the abovementioned authors, while the remaining sentences were designed by the author. Each of the seven rules/contexts for the obligatory use of the definite article were illustrated by means of three different sentences. The definite noun phrases used in these sentences varied in the grammatical category of number: the individual explanations for definite article use were illustrated by a singular countable, plural countable and uncountable noun. Furthermore, the three definite noun phrases used in the example sentences belonged to the same 'semantic field', as in coin, wallets and money used to illustrate one of the rules, or chair, chairs and furniture used to illustrate another.

\subsection{The procedure}

The verbal reports analyzed in this small-scale study were motivated by the use of a fill-inthe-blanks task. The aforementioned rules for the use of the definite article were illustrated by means of sample sentences in the task. We primarily relied on the rules/contexts classified and systematized by Lyons (1999) and Huddleston and Pullum (2002). Due to the overlap between them, seven rules/contexts for the obligatory use of the definite article finally emerged. The end result was a 31-item fill-in-the-blanks exercise which the respondents were meant to complete using a grammatical word they deemed appropriate. ${ }^{5}$

Since the goal of this study was not to evaluate the English language proficiency of the English language learner respondents, they were allowed, when necessary, to use their L1 (Serbian) while completing the think aloud task. Flexible use of both languages was meant to facilitate comprehension (cf. Lavadenz 2003).

I collected the data over a period of several weeks during the respondents' final year at university. I also doubled as the interviewer. The respondents were given the fill-inthe-blank exercise to complete and asked to verbalize the reasons for their choices, i.e. what they believed to be the most appropriate solution for each blank, and state their reasoning, in any way they could, immediately upon reaching a decision.

The respondents were all informed beforehand that the interviews would be recorded. These digital recordings were later subjected to a qualitative analysis. The interviews were held in the office of the author, outside of regular class and office hours, and each interview lasted, on average, approximately 30 minutes. In total, more than three hours of conversations were recorded and analyzed.

\footnotetext{
${ }^{4}$ I designed the questionnaire used in the research section in Dimitrijević, M. (2010). Upotreba određenog člana kod studenata anglistike: kognitivnolingvistička perspektiva (Unpublished master's thesis). University of Niš, Serbia.
} 


\subsection{Data analyses}

In his analysis, Lee (2013) 'collapsed' the four contexts for the obligatory use of the definite article previously outlined by Hawkins (1978), into two broad types: (1) anaphoric definite, based on previous mention, and (2) associative definite contexts, where reference is made to contextual factors such as shared knowledge, and post-adjectival modifications. We applied the same procedure in our analysis, and also further classified the seven contextualized rules for the obligatory use of the definite article into the same two broad contexts. The anaphoric definite contexts thus included situational use, anticipatory use, anaphoric use, and identifiability through predication, while associative definite contexts included identifiability through association, through non-linguistic knowledge, and the presence of modification.

Following Butler's (2002) taxonomy, the reasons for article choices were also broadly divided into two categories: (1) specific reasons (i.e., the respondent was able to identify one of the grammatically-based explanations he had learned in the ESL classroom) and (2) nonspecific reasons (i.e., the respondent based his choice of article on plausible choices, elimination, intuitive judgments, and even guesses). The specific reasons were classified in a manner similar to that of Lee (2013: 102): singular vs plural noun, first mention vs subsequent mention, general referent vs specific referent, countable vs uncountable noun, a combination of two or more of the above, nongeneralizable or idiosyncratic hypotheses (choices made based on knowledge of collocations or other ad-hoc rules), as were the non-specific ones (choices made based on plausibility, elimination, intuitive judgments, and educated guess work).

Based on the instructions our respondents had received during the course of their studies, we expanded the list of specific reasons to include 'uniqueness' (in such situations where the respondents would volunteer the following explanations: "because he, the player of tennis or whatever, is using just one racquet" (respondent A09). In addition, special provisions were made for the inclusion of any explanations based on of prepositional phrases, which the respondents considered sufficient grounds for identifying the referent as 'specific' and thus 'definite'.

\section{THE RESULTS}

The responses obtained from the English language learners regarding their choice of definite article and the accompanying elaborations they provided were broken down based on (1) type of explanation, primarily referring to the respondents' use of specific and non-specific reasons, (2) each individual English language learners' ability to show consistency in the provided explanations, and (3) each of the two contexts: the anaphoric definite and the associative definite context in turn.

\subsection{Specific vs non-specific reasons}

For the total 126 instances where the definite article was supposed to have been used, specific reasons used to account for its use surpass the non-specific ones by almost one half: 71 instances of the former and 50 of the latter. In the remaining 5 instances, the definite article was not used, incorrectly so.

Of the specific reasons, in 39 instances, which is more than one-half of the overall number of occurrences, the referent in question was deemed 'specific' as a result of the 
presence of modification in the noun phrase, usually used for the purpose of either linking the particular referent to the context/situation, or to indicate its 'availability' in a visual/physical sense. This was mostly achieved through the use of post-modification, i.e. relative clauses.

The second most frequently used specific reason was the use of the of prepositional phrase, which we singled out since the group of respondents recognized it as a trigger for the use of the definite article, as they had been taught to do. In total, there were 14 instances of this particular specific reason. The third most frequently used specific reason was second/prior mention, with 10 instances. Finally, the last specific reason on the list was countability, which was explicitly referred to in 8 instances.

Of the 50 non-specific reasons, our respondents most frequently resorted to the process of elimination (22 instances), educated guesswork (12 instances) and plausibility (11 instances). However, since specific reasons were our primary focus, considering that we were interested in which rules our respondents would resort to the most, there will be no further analysis of these reasons in this paper.

The results are presented in Chart 1.

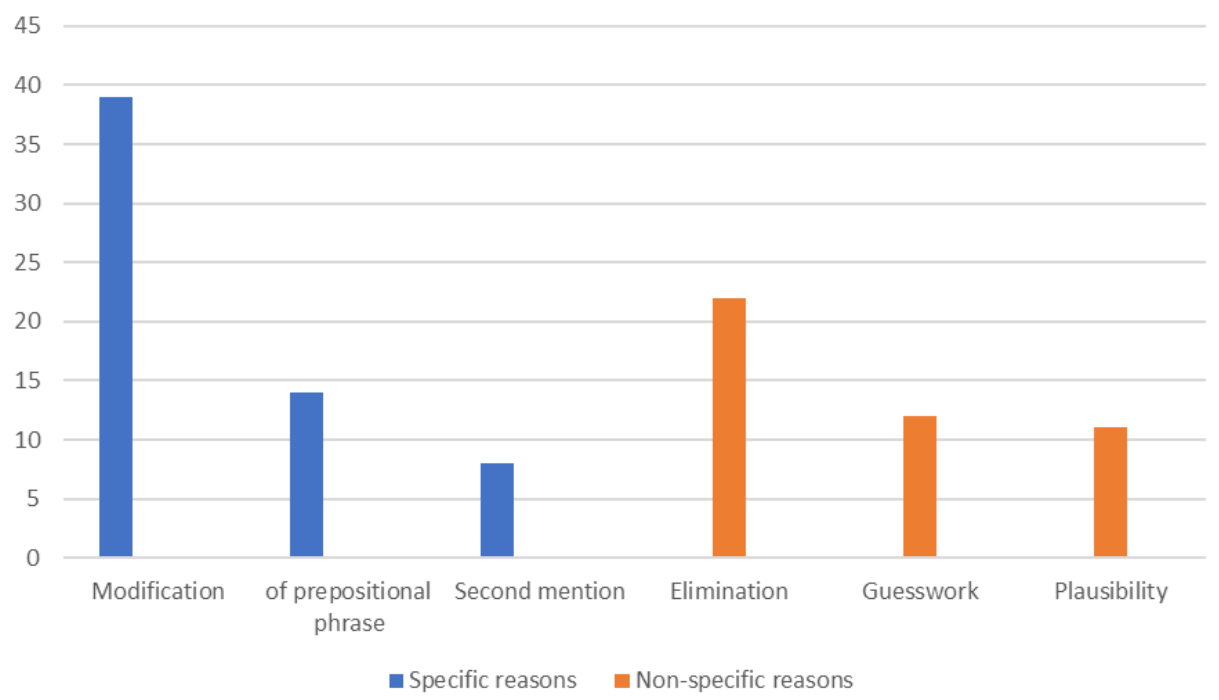

Chart. 1 An overview of the specific and non-specific responses provided by the respondents

\subsection{Consistency in individual English language learners' responses}

The responses given by each of the English language learners are presented based on the classification into anaphoric definite and associative definite contexts as follows:

\subsubsection{Respondent $\mathrm{CO} 1$}

When it comes to anaphoric use, this respondent had a tendency of establishing an association between the necessary referent and the given situation, or another referent. This they primarily achieved through modification and the use of the of prepositional phrase, or the inclusion of cleft sentences in his responses for emphasis, to single the 
referent out. Since modification can sometimes be used not only to associate one referent to another, but to explain, or indicate the presence of the referent in the visual field of the speaker, we are led to the conclusion that some respondents may rely heavily on the deictic component of determiner use, or in this case, the definite article. They also used uniqueness in an 'associative sense', to indicate the presence/belonging of one referent in a particular contextualized segment.

For associative use, the responses given did imply association, whether it was achieved by linking the referent to the situation or another referent, sometimes by means of an of prepositional phrase, or by using uniqueness to indicate that this referent is the only one of its/their kind in that context.

\subsubsection{Respondent $B O 7$}

For anaphoric use, this particular respondent needed to further provide a context in his responses which would allow disambiguation, that is, needed a situation where a demonstrative could be used instead of the definite article, in order to determine whether the referent is identifiable, thus in fact relying on the deictic component. In addition, the respondent also used cleft sentences when identifying the referent, shifting our attention to it. However, the presence of modification did not help him make a choice, and instead he relied on non-specific reasons, mostly guesswork in these instances. ${ }^{6}$

On the other hand, it would seem that this respondent had an implicit understanding of the associative definite use, even though he was not able to explicitly state that the case in point was a referent associated with another referent. It seemed as if they lacked the relevant/needed terminology to explain this connection, or link, between the referent and the given situation, or two referents. ${ }^{7}$ This respondent mostly indicated that the referent in question stood out as "the one", or "the only possible one" in the given situation/context, thus linking the referent to it. The respondent also relied on the deictic component which underlies the use of the category of determiners in general, stating that the referents in general were, predominantly, visually available to the speaker.

\subsubsection{Respondent BO6}

This respondent proved to be consistent when it comes to anaphoric definite contexts, because in almost all the examples of this type of NP context, the respondent identified the referent in question as 'specific'. This specificity was, in the words of the respondent, a consequence mostly of his ability to "explain" the referent in such a way that they were able to contextualize it, or explain how the referent fits into the existing context. This was predominantly achieved through the use of modification, which not only connected the referent to the situation/context (usually manifested through what the respondent

\footnotetext{
${ }^{6}$ Contrary to that, the other respondents seemed to have benefitted from the presence of modification, which was fitting considering that modification does allow for disambiguation. As a side note, we should indicate that this respondent made more mistakes that the other respondents in terms of definite article use, and it would seem that the use of the possessive adjective, in this respondent's eyes, makes the referent more 'specific'. Thus, there were clear signs of incongruity, or inconsistency in his responses, which might be the result of an ongoing struggle to internalize certain rules.

${ }^{7}$ This comes as no surprise as this is not one of the uses of the definite article that receives much attention in what we have referred to as the 'traditional' approach to definite article use.
} 
understood to be visually available), but usually singled it out as the only referent of that kind in this context.

For associative use, the respondent predominantly relied on the uniqueness of the referent in a particular context, linking it to at least one more referent mentioned within the same sentence, i.e. the provided context.

\subsubsection{Respondent A11}

The respondent in question relied heavily on specific reasons in anaphoric definite contexts, but unlike some other respondents (including respondents A09 and A10), they did not use the word 'specific' as much, and instead went about explaining most of the referents in relation to the other referents of the same type, indicating that it has been singled out, thus using the definite article in a pointing/deictic sense. Furthermore, their explanations were based on what we have referred to as the 'availability' of a referent, in a visual sense, to the speaker himself.

When it comes to associative use, the situation is much the same: the respondent relies on specific reasons, predominantly indicating the fact that the referent is singled out against a backdrop, once again, of either another referent mentioned in the same sentence, or a group of similar types of referents. But the specific nature of the referent is a result of an established link with other referents, implied or specified.

\subsubsection{Respondent A10}

In anaphoric definite contexts, this respondent indicated that the referents were 'specific'. The referent was rendered 'specific' based, once again, on 'availability' in a way, and the respondent explained that the referent is 'linked' to the situation at hand. The specificity of the referent was explained in sentences which relied mostly on modification, on relative clauses, which link the referent in question to another mentioned referent.

When it comes to associative definite contexts, the predominant explanation for a referent being 'specific' is that there is a 'link' between it and another referent.

\subsubsection{Respondent A09}

This respondent relied predominantly on specific reasons to account for the use of the definite article in anaphoric definite contexts, indicating that the referent in question was mostly a specific rather than a general one. To identify the referent as specific, this respondent mostly relied on indicating its 'availability' in the context, the use of an of prepositional phrase in the given sentence, or referring to its identification based on uniqueness.

In the associative definite contexts, predominantly specific reasons were once again used to indicate that the referent was specific.

\subsection{Anaphoric definite contexts}

\subsubsection{Situational use}

In this particular context, definite article use is most similar to, and overlaps with, the use of demonstratives. In the Serbian language, many situations involving referential relations are often resolved by using demonstratives, and some of our English language learners responded accordingly during the interviews. For example, in one particular 
sentence included in the fill-in-the-blank task, the correct answer was the shelf, but it was not infrequent that the responses included the phrase that shelf (Sentence 28: Please wipe shelf before you put something on it.). The respondents went on to claim that the reason for their choice was, in fact, the context: the speaker and hearer could both see the shelf in question, which made the use of the demonstrative quite appropriate in their minds. This sort of explanation was the most frequent one for the sample sentence containing the noun chairs as well (Sentence 27: chairs will have to be moved in case something goes wrong). However, when it came to the uncountable noun furniture (Sentence 2: ___ furniture has not been arranged properly.), the respondents often stated that this was an uncountable noun, as if it were the most important piece of processing information when it comes to definite article use, and did not rely on the same criteria which accounted for the use of the definite article with the noun 'shelf'.

\subsubsection{Anticipatory use}

This explanation for this use of the definite article most closely resembles the course book rule of using the definite article with of prepositional phrases in the English language, and it was the answer of choice for most of the respondents. They mostly referred to it specifically, naming it explicitly, to indicate that the inclusion of this phrase made the referent specific.

\subsubsection{Anahporic use}

This explanation for the use of the definite article is an easily accessible one, as our respondents frequently stated "mentioned in the previous sentence", "ono pravilo" (Eng. oh, you know, that rule), in combination with citing the uniqueness of the given referent. Here we clearly see that uniqueness cannot account for all uses of the definite article because in the example women (Sentence 16: Two women and several children walked into the restaurant. I knew women from somewhere.), there were no doubt more women present on the premises, and uniqueness cannot explain why the definite article is necessary, and would require us to invoke Hawkins' (1978) rule of 'maximality' in a particular context.

\subsubsection{Predication}

This explanation for the use of the definite article might appear to be one of the more difficult rules to apply, if for no other reason than the fact that it requires an English language learner to refer to the context set up within the sentence itself, and we have so far been able to glean that it is easier for our respondents to rely on syntactic constituents, as included in specific reasons, rather than any contextual information to account for definite article use. For this particular explanation, in the three illustrations, in one case the respondents preferred not to use an article with the noun dogs (Sentence 18: Beware of ___ dogs!), in the case of the noun anger (Sentence 31: All of a sudden, anger got so strong it made it impossible for her to speak.) they used a possessive adjective more than often than a definite article, and only in the case of the word racquet (Sentence 19: racquet dropped from his hand as if it had grown numb.) did the

\footnotetext{
${ }^{8}$ All of the sentences included in the fill-in-the-blank task can be found in Appendix at the end of this paper.
} 
respondents refer to the context, and instead of referring to the racquet as a constituent element of the situation of playing tennis, they opted for indicating that the racquet was unique, that each tennis player only had one racquet to play with at a time.

\subsection{Associative definite contexts}

\subsubsection{Through association}

This particular type of explanation for definite article use also most closely resembles what our respondents identify as one of the standard rules for definite article use: using the definite article with of prepositional phrases. Most of the respondents in the study linked the given referents by means of syntactic constituents to other referents, explicitly or implicitly stated. Thus, many of the interviewed respondents opted for this explanation when providing answers for the fill-in-the-blank items which fell under this particular category, although association was not explicitly mentioned. In this case, in addition to referring to the use of the of prepositional phrase, the respondents were also prone to referring to uniqueness, that is, saying that there was only one example of each of the referents in a particular situation: one pilot per plane (Sentence 17: Five planes landed early today. _ pilots were having fuel problems.), or just one battery in a car (Sentence 15: My car won't start. ___ battery must be dead.). In addition, for the noun information (Sentence 1: I'm looking at the timetable right now. ___ information is all wrong!) they also opted for other solutions. In one case, a respondent indicated that the demonstrative this was called for, since both of the individuals involved in the speech situation had a clear view of the timetable where the information was located, which means that he concluded that 'pointing' to the referent was called for. Furthermore, it was not just a case of the information being 'available' or 'visible', there was also the issue of the countability of the given noun. This again came as no surprise considering the fact that this particular noun is often cited in many course books as being a prime example of an uncountable noun which requires not only the singular form of any verb, but also, one which English language learners perceive to be exempt from certain article use.

\subsubsection{Non-linguistic knowledge}

When accounting for the use of the definite article in the items used to illustrate nonlinguistic knowledge, our respondents often relied on syntactic constituents such as of prepositional phrases, relative clauses and modifiers. They relied on these constituents in the guise of specific reasons, to indicate that each of the referents in question was 'specific', as in "a specific government", "a particular group of firemen" (Sentence 7: firemen did not get there on time.) and "[president] konkretan" (in English: specific), (Sentence 25: I heard___ president was behaving inappropriately.). As in the case of association, they were able to indicate that the referent was "specific" or "unique" in the given context, thus linking the referent to the particular situation. "That specific $X$ ' is unfortunately an inadequate explanation for their choice of the definite article, not only because they were not able to phrase their thoughts and assumptions correctly, but because we cannot be sure as to how they will rely on a rule of this kind in the future, i.e. whether it is "productive" in the sense that it would lead to more frequent correct uses of the definite article, rather than incorrect ones. However, due to the type of rules which they have learned over the course of their language instruction, the respondents have not explicitly been instructed on the links which could be established 
between two referents or one referent and a particular situation, although we may have reason to conclude that some of them intuitively do have an understanding of this.

\subsubsection{Modification}

When accounting for the use of the definite article in the items used to illustrate nonlinguistic knowledge, our respondents often relied on syntactic constituents such as of prepositional phrases, relative clauses and modifiers. They relied on these constituents in the guise of specific reasons, to indicate that each of the referents in question was 'specific', as in "a specific government", "a particular group of firemen" (Sentence 7: firemen did not get there on time.) and "[president] konkretan" (in English: specific), (Sentence 25: I heard__ president was behaving inappropriately.). As in the case of association, they were able to indicate that the referent was "specific" or "unique" in the given context, thus linking the referent to the particular situation. "That specific $X$ ' is unfortunately an inadequate explanation for their choice of the definite article, not only because they were not able to phrase their thoughts and assumptions correctly, but because we cannot be sure as to how they will rely on a rule of this kind in the future, i.e. whether it is "productive" in the sense that it would lead to more frequent correct uses of the definite article, rather than incorrect ones. However, due to the type of rules which they have learned over the course of their language instruction, the respondents have not explicitly been instructed on the links which could be established between two referents or one referent and a particular situation, although we may have reason to conclude that some of them intuitively do have an understanding of this.

In this case, the responses seem to revolve mostly around the concept of uniqueness, as if there were only one referent of a particular kind, and that the description offered is an indication of its unique status. Contextual uniqueness may be an apt way of accounting for definite article use in some situations, but it leaves no room for establishing relations among different referents, be they existing, implied, permanent or temporary. The respondents frequently mentioned terms such as "visible" and "available" which leads us back to demonstratives and the necessity of the referents being physically/visually available. However, when it comes to the aforementioned situational use, as previously indicated, the respondents prefer demonstratives to the definite article, even though visual availability was a criterion stipulated in both cases. This might imply a gradation of the criteria.

\section{DISCUSSION}

We begin this section by offering responses to the research questions proposed above.

In response to question number one, the respondents who participated in the interviews preferred specific reasons for the use of the definite article, and the way they used these reasons warrants further discussion.

The term 'specific' was used by our respondents in the sense of 'one', or for uniqueness, as in the examples provided by respondent B06: "specific situation, there is only one battery in the car", or uniqueness amplified though modification, "it's one specific coin that my grandpa gave to me", uniqueness supported by prior mention "although it is only one boy, a boy, it has already been mentioned, so... specific", or uniqueness which is achieved by setting the referent in question apart from a group of similar referents, as in the example provided by respondent $\mathrm{C} 01$ : “it's not any prospect, the one prospect.. it's specific". 
At other times the term 'specific' was used by the respondents to indicate something that is visually accessible, as indicated in the explanation provided by respondent A09: "looking at a room full of furniture", and respondent A11: "because it's a particular wallet, I imagine it stands there somewhere on the table", or that is otherwise 'available' to the respondents in the speech situation, as in the responses provided by respondent A09: "as specific shelf the person is talking about", A11: "we think about shelf, and we know which shelf that is", "the anger she was feeling at the moment, we know which anger we are talking about", or respondent B06: "I suppose that both the speaker and listener both know which chairs".

Furthermore, 'specific' was also taken to indicate possession, as illustrated in an example provided by respondent A09: "her anger, it's specific", and A10: "pa nečiji, neki konkretan predmet" (Eng. well it must be someone's, it's a specific object).

To be more precise, the referents in question were rendered 'specific' through explanations based on the use of modification, which was the most frequently used specific reason for definite article use in both anaphoric definite and associative definite contexts, mostly through the use of either the of prepositional phrase or relative clauses as the key syntactic constituents used for this purpose.

When it comes to question number two, unlike the results obtained by Lee (2013), advanced English language learners did not perform better for anaphoric reference than they did for associative reference tasks. It did not seem that they in any way distinguished between the two in terms of their responses or provided explanations, in the sense that even in anaphoric definite contexts, 'association' achieved by means of explanations provided by the use of the of prepositional phrase, was used to link the referent, albeit implicitly, to either other referents of its type, or another referent found in the given context/situation.

In this sense, the respondents at times seemed to be singling referents out (and when doing so, they indicated that the nouns in question were "defined") by what can at this point most accurately be explained as their invoking an associative definite context, whether the example they were referring to was actually classified as belonging to these contexts or not. For example, respondent A09 stated the following: "the battery of my car, not any car" in which case the use of the of prepositional phrase is combined with the possessive adjective to single a referent out albeit in an appropriately associative definite context, or "two specific ideas, not any idea" where the quantifier 'any' was used in an anaphoric definite context to also single out a referent from a group of similar referents.

Respondent A10 also singled out several referents by linking them to other referents in their proximity, or by establishing an association between them: "pa to su piloti ovih aviona" (Eng. well, those are the pilots of those planes), or as respondent A11 stated, "the sentence is about those pilots", in which case his use of the demonstrative pronoun singled out a group of referents in an associative definite context.

Next, respondent B06 gave the following explanations: "it's probably not any furniture, but it's the furniture in the room where the... speaker... is". This example was meant to illustrate what is known as the 'situational use' of the definite article, which refers to the referent being visually/physically 'available' in the given context, to both interlocutors, but the explanation provided indicates more than that, as it not only indicates the referent's location, but also singles it out by implying that it is the focus of their attention. The same respondent repeated this particular type of explanation in the example meant to illustrate the required use of the definite article through modification of the noun in question in "it's not 
any money, but the money you found on the street", an explanation which precisely through the use of the quantifier 'any' indicates emphatic use.

Respondent B07 also relied on demonstrative pronouns in the Serbian language to single out the referent in question: "pa se to odnosi baš na taj akumulator iz tog automobila" (Eng. well it refers to that specific battery in that specific car) in an associative definite context, "zato što se ne odnosi na sve [pilote]" (Eng. because it does not refer to all the pilots in the world), in an associative definite context, and "deda mu je dao samo jedan novčić, našao je baš taj jedan" (Eng. his grandpa gave him only one coin, and he found that one particular coin) once again, with the same emphatic effect, in an anaphoric definite context in which the use of the definite article is required due to the inclusion of modification in the noun phrase.

Further examples of 'singling' referents out include the following:

Sentence 1: I'm looking at the timetable right now. information is all wrong!

Sample response: "zato što gramatički može, ali onda se samo odnosi na jedno, da jedna brojka nije dobra ne na celokupan raspored" (Eng. because grammatically it's possible, but then it only refers to one thing, to just one number not being correct in the entire schedule)

Sentence 5: government has already answered that question.

Sample response: "ako kažemo the government onda podrazumevamo da tu ima još neka druga vlada" (Eng. if we were to say 'the government' then than would mean there is some other government as well)

Sentence 10: We were worried about prospect of having to cook for six.

Sample response: "cooking has several sides, and you're worried about one of those sides"

In addition, in both the anaphoric definite and associative definite contexts, the responses obtained from the respondents indicated an implicit reliance on the deictic component of the definite article, as they often made references to what would visually be 'available' to the respondents in the communicative situation "ali kad je the onda moraju nekako da budu vidljivi i da budu prisutni“" (Eng. but if we use 'the' that means that they have to be visible somehow, and to be present). This deictic component was often to be found in the form of demonstratives included in the respondents' explanations/accounts of the use of the definite article. This particular occurrence was not in fact unexpected, due to the preference for using demonstrative pronouns in their native language to 'single' referents out, or indicate their salience in the given context. Some sample responses include the following:

Sentence 19: racquet dropped from his hand as if it had grown numb.

Sample response: "Ovde verovatno utiče moj maternji jezik... pa je zato bolje pokazna zamenica" (Eng. my native language is probably interfering here... that's why it's better if we were to use a demonstrative pronoun)

Sentence 27: chairs will have to be moved in case something goes wrong.

Sample response: "these, those... chairs that are there; I guess it's somewhere in a room"

Sentence 28: Please wipe shelf before you put something on it.

Sample response: "in this case there would... more than one shelf in the room" 
Sentence 7:___ firemen did not get there on time.

Sample response: "I always create a context: I think about the sentence, I visualize the situation, I think about it, I imagine a fire burning somewhere..."

Sentence 31: All of a sudden, anger got so strong it made it impossible for her to speak.

Sample response: "because we know which anger we are talking about, it's the immediate anger"

The influence of the respondents' native tongue can be seen in the following examples, where the use of possessives was expected since they are used to indicate specificity in the Serbian language. At this point we can refer to the already established relationship of using adjectives (including possessive adjectives) to convey meanings inferred by the use of the definite article, which is typical of Serbian (L1) learners of English (L2) (Trenkić 2002, 2004, 2007, 2008). Sample responses include the following:

Sentence 3: power of holding down two executive positions finally went to his head.

Sample response: "his zamenjuje the, mislim da se značenje ne menja, isto se odnosi na njega" (Eng. 'his' can be used to replace 'the', I don't think there is any difference in the meaning, it also refers to him)

Sentence 14: ideas that he would both have to drive and wait for her made him angry.

Sample response: "the ideas i his ideas, to bi bilo isto" (Eng. "the ideas' and "his ideas', it's the same thing)

Sentence 31: All of a sudden anger got so strong it made it impossible for her to speak.

Sample response: "it is she, anger cannot be used in this sense for generic meaning, but it is specific, it is her emotion"

In response to question number three, the results of the analysis indicate a lack of inconsistency in the offered answers, and only infrequently were various accounts provided, unlike in Ellis (1991) where advanced Chinese learners of English demonstrated considerable inconsistency in their judgments, relied extensively on "feel" in order to make a judgment, and were not successful in using explicit grammatical knowledge to make judgments. Our respondents mostly relied on the same explanations for the same examples, primarily as indicated previously, by using modification, the of prepositional phrase and 'linking' referents together.

\section{CONCLUSION}

Understanding definite article use in particular, and the English article system in general does not simply boil down to memorizing rules, but understanding reference, point of view, and the influence of the context. As indicated by Master (1990), Ellis (1991) and Lee (2013), many criteria need to be taken into consideration for article selection, including, but not limited to, definiteness, countability, and noun number of NPs. The simultaneous processing of all these criteria is a complicated task because each of these distinctions is not inherent in lexical items, but highly dependent on a given discourse context, and this usually leads to excessive cognitive load. In this particular small-scale study, we attempted 
to determine whether it was possible, and if so to which extent, to gather information on how our respondents notice/understand the rules (or rather, cues) for the use of the definite article (contextual and grammatical), as well as which cues they do notice and which ones they do not. Thus, our goal was to determine whether it would be possible to rely on a think-aloud protocol to try and capture at least one part of the reasoning behind (not) using the definite article in the English language, as presented by a group of English language learners.

In an effort to determine which rules English language learners rely on the most, we attempted to make assumptions about which rules they have learned first, or best. Based on the structure of the questionnaire, we analyzed the types of responses which the respondents gave for each type of definite article use, with the hope of gaining information which might facilitate and also improve the learning process. In particular, our aim was to give an explanation of how Serbian (L1) learners of English (L2) at the tertiary level account for the use of the definite article, and what they notice in the given language material which might be reflected in the choice of article. Due to the frequency of errors (primarily article omission or incorrect use), we cannot always be sure that our students are using the right article to convey their desired meaning. If we were to help them identify and bridge this gap it might go a long way towards helping them overcome this key feature of the English language which is a necessary component of determining proficiency.

The results, albeit limited by the size of the sample of respondents, do indicate a certain tendency in terms of which explanations this group of English language learners relied on the most, i.e. specific, and how they accounted for the particular 'specific' position of the referent in question in relation to the other referents, i.e. by relying on modification, the use of the of prepositional phrase and making implicit associations in most cases. Furthermore, the presence of demonstrative pronouns both in the responses they provided in the fill-inthe-blank task and the explanations they gave during the interviews indicated the influence of the syntactic constituents used in their native tongue to achieve what they perceived to be the same effect as that of the definite article: demonstratives and possessive adjectives.

But even these conclusions must be viewed in a broader context with the following in mind: a) that English language learners can assign a definite or indefinite status to a nominal depending on their perspective and interpretation of the referent in a particular context; b) that English language learners sometimes develop idiosyncratic hypotheses with regard to the use of the definite article; c) that as Butler (2002) indicated, it is not always clear to what extent English language learners access metalinguistic knowledge in production activities, etc.

In summary, it would seem that our respondents are capable of establishing links between referents by means of various syntactic constituents, and there might even be the possibility of considering that instruction based on these links, in a different framework, could potentially be of use in the foreign/second language classroom. Based on these types of spontaneous explanations, the case could be made for alterations in the instructions that English language learners receive. White (2010) also criticized the criteria presented in these ESL grammar books for making article choices, citing that they were based more on collocations, particular words or constructions rather than conceptualizations which a speaker wishes to convey or broader discursive contexts, which only hindered the instruction and learning process. 


\subsection{Further research}

As indicated, a study which included such a small sample of respondents does of course carry with it certain limitations, especially in terms of generalizability of the results. It can merely be evaluated as a first step. A further qualitative study that would include more respondents is called for, not only in terms of attempting to collect more data, but the attempt to validate this method of data elicitation in this particular field of study. Furthermore, we are faced with another problem, which is the lack of use of think-aloud protocols in the Serbian EFL context which renders the comparison and exchange of data difficult.

In terms of the very practical issues which came up during the preparations for the small-scale study and its realization, it proved to be quite difficult to motivate students to participate in this type of data elicitation process. They mostly seemed to be selfconscious about their knowledge and reasoning, and unsure of how to proceed. More attention needs to be paid to the problem of motivating respondents.

In addition, in any further attempts of this type, it would be useful to consider asking more to-the-point questions such as What in your opinion is the deciding factor for the use of the definite article: the immediate context (what can be seen in the given situation, how we imagine/visualize it) or the presence of grammatical structures in the sentence (adjectives, a relative clause, an of phrase?

Further studies could also focus on the distinctions between implicit and explicit knowledge of the use of the definite article in English, by comparing the account which the same English language learners give of the use of the definite article and their production of the definite article (following Lee 2013). Furthermore, since the main data elicitation method used in this study was the think-aloud protocol, which focuses on oral production, it would be worthwhile to analyze how English language learners use the definite article in their writing, especially in the context of noun phrases which contain a modifier (following Trenkić 2007).

More attention needs to be paid to properly considering discourse and context-related factors. In order to achieve this, it might be worthwhile to consider the use of unified segments of a text for definite article instruction, rather than individual examples. This practical step could be accompanied by a change in the theoretical framework as well, where context is readily accounted for, such as mental space theory (Fauconnier 1985/1994) or frame semantics (Fillmore 1976). If tested appropriately in practice, a different theoretical framework could provide a more readily available and more encompassing explanation for the use of the definite article. Thus, potentially semantic frames could be introduced into the EFL classroom to account for the associations they make, the figure/ground distinction could be introduced to account for the deictic component, and mental space theory could provide the backdrop for accounts of definite article use which have so far been treated as 'exceptions'. Theoretical work on the subject has already been done and can be found in the work of Epstein (1999, 2001). An empirical evaluation of the proposed hypotheses could teach us more about how EFLs understand the use of the definite article.

Even though there may be potential issues regarding reactivity and the think-aloud protocol as a method of data elicitation, since verbalization tends to increase overall task completion time, its benefits would seem to outweigh these potential issues, especially when it comes to studies such as this one, where the duration of processing time was not a variable of interest. In this case, we were interested in which of the conditions set up to 
indicate definite article use are relevant for a particular sample of English language learners, for a cursory glimpse into their decision-making process when they encounter difficulty with a text (Lavandenz 2003), and to avoid speculation on issues which we have previously had no access to, such as which of the rules for definite article use would be used the most by Serbian (L1) learners of English (L2). To quote Wigglesworth (2005: 101)

"In focussing on the following methodologies, I would point out that my concern is not with the measurement of what learners know (i.e., the end product of learning), but rather with the process of identifying what it is that learners focus on as they move toward increasing their proficiency in their second language. The challenge for all these methodologies is to obtain observable, externalized data from unobservable, internalized processes to draw conclusions about the processes."

Furthermore, Leow (2006) outlined some of the important work done on the facilitative role of attention and awareness in SLA which is of paramount importance for learning to take place. Think-aloud protocols can help respondents focus their attention on aspects they may have neglected in the past: the difference between what they know and what they think they know, what they think that can say in the L2 and what they can actually say. To avoid any bias on the part of the author, it should be pointed out that we agree with Jourdenais (2001) that learners do not/cannot verbalize everything that they notice, nor can a further point made by the same author be ignored: that the respondents' verbalization might incompletely or inaccurately reflect their thinking processes. However, participating in think-aloud protocols could actually prove to be a productive learning experience for the respondent, not merely a means of data elicitation for the researcher.

\section{REFERENCES}

Bowles, M. A., and Leow, R. P. (2005). Reactivity and type of verbal report in SLA research methodology. Studies in Second Language Acquisition, 27, 415-440

Bowles, Melissa A. (2008). Task type and reactivity of verbal reports in SLA: A first look at an L2 task other than reading. Studies in Second Language Acquisition 30.3, 359-387.

Bowles, Melissa A. (2010). The think-aloud controversy in language acquisition research. London: Routledge.

Butler, Y. G. (2002). Second language learners' theories on the use of English articles. Studies in Second Language Acquisition, 24, 451-480.

Corder, S. P. (1975). Error analysis, interlanguage and second language acquisition. Language teaching 8(4), 201-218.

Dimitrijević, M. (2010). Upotreba članova kod studenata anglistike: kognitivnolingvistička perspektiva. (In Serbian). Unpublished master's thesis. Faculty of Philosophy, University of Niš.

Ellis, R. (1991). Grammaticality judgments and second language acquisition. Studies of Second Language Acquisition, 13, 161-186.

Epstein, R. (1999). Roles, frames, definiteness. In Van Hoek, K., Kibrik, A. A. and Noordman, L. (Eds.). Discourse studies in cognitive linguistics: Selected papers from the 5th International Cognitive Linguistics Conference, Amsterdam, July 1997. (53-74). Amsterdam/Philadelphia: John Benjamins Publishing Company.

Epstein, R. (2001). The definite article, accessibility, and the construction of discourse referents. Cognitive Linguistics 12, 4, 333-378.

Ericsson, K. A., and Simon, H. A. (1993). Protocol analysis: Verbal reports as data. Cambridge, MA: MIT Press.

Fauconnier, G. (1985/1994). Mental spaces. Cambridge: CUP.

Fillmore, C. J. (1976). Frame semantics and the nature of language. Annals of the New York Academy of Sciences: Conference on the Origin and Development of Language and Speech, Volume 280, 20-32.

Gass, S. M. and Mackey, A. (2007). Data elicitation for second and foreign language research. New York/London: Routledge. 
Hawkins, J. A. (1978). Definiteness and indefiniteness. London: Croom Helm.

Huddleston, R. and Pullum, G. K. (2002). The Cambridge grammar of the English language. Cambridge: Cambridge University Press.

Ionin, T., Baek S., Kim, E., Ko, H., and Wexler, K. (2012). That's not so different from the: Definite and demonstrative descriptions in second language acquisition. Second Language Research, 28, 1, 69-101.

Jarvis, S., and Pavlenko, A. (2008). Crosslinguistic Influence in Language and Cognition. New York: Routledge.

Jespersen, O. (1949). A Modern English Grammar on Historical Principles. Part VII: Syntax. Completed and edited by Niels Haislund. London: George Allen and Unwin; Copenhagen: Ejnar Munksgaard.

Jourdenais, R. (2001). Protocol analysis and second language instruction. In Robinson, P., (Ed.), Cognition and second language instruction. Cambridge: Cambridge University Press, 354-376.

Lavadenz, M. (2003). Think aloud protocols: teaching reading processes to young bilingual students. (December 2003). ERIC Digest EDOFL-03-14. Center for Applied Linguistics: Washington, D.C.

Lee, J. (2013). A comprehensive study of the use of English articles by Korean L2 speakers of English: Speaking, writing, and metalinguistic awareness. Unpublished doctoral dissertation. The Graduate School of Education Rutgers, The State University of New Jersey.

Leow, R. P. and Morgan-Short, K. (2004). To think aloud or not to think aloud: The issue of reactivity in SLA research methodology. SSLA, 26, 35-57.

Leow, R. P. (2006). The role of awareness in 12 development: theory, research, and pedagogy. Indonesian Journal of English Language Teaching, 2 (2), 125-139.

Lyons, C. (1999). Definiteness. Cambridge: CUP.

Master, P. (1990). Teaching the English articles as a binary system. TESOL Quarterly, 24, 3, 461-478.

Master, P. (2003). Acquisition of the Zero and Null Articles in English. Issues in Applied Linguistics, 14, 1, 3-20.

Matthews, D., Lieven, E., Theakston, A. and Tomasello, M. (2006). The effect of perceptual availability and prior discourse on young children's use of referring expressions. Applied Psycholinguistics 27, 403-422.

Mayo, M.P.G. and Hawkins, R. (2009). (Eds.) Second language acquisition of articles: empirical findings and theoretical implications. Amsterdam: John Benjamins Publishing Company.

Radden, G. and Dirven, R. (2007). Cognitive English Grammar. Amsterdam/Philadelphia: J. Benjamins Publishing Company.

Thomson, A. J. and Martinet, A.V. (1986/2004). A practical English grammar. Oxford: OUP.

Trenkić, D. (2002). Establishing the definiteness status of referents in dialogue (in languages with and without articles). Working Papers in English and Applied Linguistics 7, 107-131.

Trenkić, D. (2004). Definiteness in Serbian/Croatian/Bosnian and some implications for the general structure of the nominal phrase. Lingua 114, 1401-1427.

Trenkić, D. (2007). Variability in L2 article production: beyond the representational deficit vs processing constrains debate. Second Language Research 23, 3, 289-327.

Trenkić, D. (2008). The representation of English articles in second language grammars: Determiners or adjectives? Bilingualism: Language and Cognition 11, 1, 1- 18.

Veličkovic, M. (2017). Upotreba određenog člana u engleskom jeziku u teoriji mentalnih prostora: mogućnost primene u nastavi engleskog kao stranog jezika. In Serbian. Unpublished doctoral dissertation. University of Niš, Faculty of Philosophy.

Verspoor, M. and Huong, N. T. (2008). Cognitive Grammar and teaching English Articles to Asian Students. In Lapaire, J.R. (Eds.) From Gram to Mind: Grammar as Cognition. 249 - 268. Bordeaux: Presses Universitaires de Bordeaux.

Verspoor, M. (submitted) Using Metaphors in Teaching English Articles. In Juchem-Grundmann, C. and Niemeier, S. (Eds.), KNOWING IS SEEING: Metaphor and Language Pedagogy. Berlin: Mouton de Gruyter.

Vince, M. (2003). Advanced language practice. London: Macmillan.

White, B. J. (2010). In search of systematicity: A conceptual framework for the English article system. Ann Arbor: UMI Dissertation Publishing, ProQuest.

Wigglesworth, G. (2005). Current approaches to researching second language learner processes. Annual Review of Applied Linguistics 25, 98-111. 


\title{
UPOTREBA 'THINK ALOUD' PROTOKOLA U PROCENI ZNANJA O UPOTREBI ODREĐENOG ČLANA KOD STUDENATA ENGLESKOG JEZIKA U SRBIJI
}

\begin{abstract}
Jedan od problema koji nije dovoljno razmatran na srpskom govornom području je kako izvorni govornici srpskog jezika koji studiraju engleski jezik donose odluku o tome koji su kriterijumi dovoljni i prikladni za upotrebnu određenog člana u engleskom jeziku. Potencijalni odgovori na ovo pitanje mogli bi pomoći u prepoznavanju ključnih problema u upotrebi određenog člana, kako bi studenti nadalje mogli da dobiju eksplicitna uputstva prilagođena upravo njima. Takođe bi se moglo doći do specijalizovanog pristupa koji bi se mogao primenjivati na ovoj populaciji studenata engleskog jezika. Pilot istraživanje u kome su učestvovali studenti Departmana za anglistiku Filozofskog fakultetu Univerziteta u Nišu sprovedeno je sa pomenutim ciljem. U istraživanju smo koristili 'think-aloud' protokol i posebno osmišljen upitnik kako bi od ispitanika prikupili podatke o tome na koja se pravila pozivaju kada upotrebljavaju određeni član $u$ različitim anaforičkim i asocijativnim kontekstima.
\end{abstract}

Ključne reči: srpski učenici engleskog jezika, određeni član, 'think-aloud' protokol

APPENDIX

Uputstvo:

Pre svega bismo želeli da Vam se zahvalimo što ste pristali da nam pomognete popunjavanjem ovog upitnika. Naše istraživanje tiče se načina na koji osobe čiji je maternji jezik srpski upotrebljavaju neke vrste reči u engleskom jeziku. Ovo nije ispit tako da ne postoje "tačni" i "netačni" odgovori, i upitnik je potpuno anonima tako da čak i ne morate da nam date Vaše ime. Nas interesuje samo kako biste odgovorili na sledeća pitanja. Jedino što Vas molimo je da odgovorite što iskrenije i prirodnije, jer će to biti naša garancija za uspešno sprovedeno istraživanje. Još jednom hvala na izdvodjenom vremena.

Ponudićemo Vam 31 rečenicu u kojima ostavljenu prazninu valja popuniti nekom reči. Ukoliko nemate odgovor, molimo da u prazan prostor koji je ostavljen ubeležite N/A.

1. I'm looking at the timetable right now. information is all wrong!

2. ___ furniture has not been arranged properly.

3. power of holding down two executive positions finally went to his head

4. He says he saw ___ falling star when he was a child.

5. __ government has already answered that question

6. Do you also like ___ chess?

7. firemen did not get there on time.

8. Everybody is taking bills from brown wallets.

9. They have a boy and two girls. ___ boys is still a baby.

10. We were worried about ___ prospect of having to cook for six.

11. He bought ___ new car this morning.

12. She thought we'd go for ___ long walks in the mountains, but no one wanted to.

13. Some people entered our yard. Even though it was dark, I could see ___ people were carrying bricks.

14. ___ ideas that he would both have to drive and wait for her made him angry. 
15. My car won't start! I think battery is dead.

16. Two women and several children walked into the restaurant. I knew women from somewhere.

17. Five planes landed early today.

18. Beware of pilots were having fuel problems.

20. appearances can be deceiving.

21. John became ___ businessman.

22. Could you give me ___ hand?

23 . music can be soothing.

24. I only just found ___ coin my grandfather gave me.

25. I heard that ___ president was behaving inappropriately.

26. money you found on the street has to be returned to its rightful owner.

27. ___ chairs will have to be moved in case something goes wrong.

28. Please wipe ___ shelf before you put something on it.

29. He insists on buying ___ books every month.

30. I need_ pen, but I didn't bring one.

31. All of a sudden, ___ anger got so strong it made it impossible for her to speak. 